\title{
Globalization and the Law: Deciphering the Message of Transnational Human Rights Litigation
}

Peer Zumbansen

Osgoode Hall Law School of York University, pzumbansen@osgoode.yorku.ca

Source Publication:

German Law Journal. Volume 5, Number 12 (2004), p. 1499-1520.

Follow this and additional works at: https://digitalcommons.osgoode.yorku.ca/scholarly_works (c) (1) $(9)$

This work is licensed under a Creative Commons Attribution-Noncommercial-No Derivative Works 4.0 License.

\section{Recommended Citation}

Zumbansen, Peer. "Globalization and the Law: Deciphering the Message of Transnational Human Rights Litigation." German Law Journal 5.12 (2004): 1499-1520.

This Article is brought to you for free and open access by the Faculty Scholarship at Osgoode Digital Commons. It has been accepted for inclusion in Articles \& Book Chapters by an authorized administrator of Osgoode Digital Commons. 


\title{
SPECIAL ISSUE
}

\section{Globalization and the Law: Deciphering the Message of Transnational Human Rights Litigation}

\author{
By Peer Zumbansen*
}

\section{A. Ouverture ${ }^{* *}$}

On 14 October 2004, the Bundesverfassungsgericht (BVerfG - German Federal Constitutional Court) voided a decision by the Oberlandesgericht (Higher Regional Court ) Naumburg, finding a violation of the complainant's rights guaranteed by the Grundgesetz (German Basic Law). ${ }^{1}$ The Decision directly addresses both the observation and application of case law from the European Court of Human Rights under the Basic Law's "rule of law provision" in Art. 20.III. ${ }^{2}$ While there is a myriad of important aspects with regard to this decision, we may limit ourselves at this point to the introductory aperçu contained in the holdings of the case. One of them reads as follows:

Zur Bindung an Gesetz und Recht (Art. 20 Abs. 3 GG) gehört die Berücksichtigung der Gewährleistungen der Konvention zum Schutze der Menschenrechte und Grundfreiheiten und der Entscheidungen des Europäischen Gerichtshofs für Menschenrechte im Rahmen methodisch vertretbarer Gesetzesauslegung. Sowohl die fehlende Auseinandersetzung mit einer Entscheidung des Gerichtshofs als auch

\footnotetext{
* Canada Research Chair in the Transnational and Comparative Law of Corporate Governance, Osgoode Hall Law School, York University, Toronto, Canada. Co-Editor in Chief, German Law Journal (http://www.germanlawjournal.com). Email: PZumbansen@osgoode.yorku.ca.

** This paper was presented at the Second International German Law Journal Workshop: “The Political Economy of Jurisdictional Competences for Human Rights", held at Duke University School of Law, Durham, North Carolina, 29 October 2004. My thanks go to Kelly Gallenstein and GLJ Co-Editor Ralf Michaels for organizing the event for the German Law Journal. I am grateful for comments from Russell Miller as discussant, Cesare Romano as Chair of the panel, and from the Workshop participants and Alexander Hanebeck (Frankfurt).

${ }^{1}$ See the decision at: http://www.bverfg.de/entscheidungen/rs20041014_2bvr148104.html.

2 "The legislature shall be bound by the constitutional order, the executive and the judiciary by law and justice."
} 
deren gegen vorrangiges Recht verstoßende schematische "Vollstreckung" können gegen Grundrechte in Verbindung mit dem Rechtsstaatsprinzip verstoßen. ${ }^{3}$

This holding goes to the heart of any discussion of transnational law. With the rise of human rights standards within the sphere of transnational civil human rights litigation since Filartiga, ${ }^{4}$ it has become ever more difficult to discern the borders and divisions of law. In our assessment of border-crossing legal (and other) standards, our focus on law as a contained system of rules guides our perception and our evaluation of what in fact must be recognized as a highly differentiated, fragmented and decentralized interlocking of regulatory and self-regulatory processes. ${ }^{5}$ This development not only concerns territorial borders or the doctrinal confines of public and private law. ${ }^{6}$ The reference in the cited decision of the Federal Constitutional Court to methodological sovereignty in asserting its right to review the case law of the European Court of Human Rights (instead of "schematically executing" the holdings of this supranational court) serves as an urgent reminder of the need to dive into a more thorough research of the possibilities and the scope of such methodological self-constraint. The Federal Constitutional Court itself, however, offers little guidance as to the adequate ways in which we may confront the methodological pressure on law in an Era of Globalization. ${ }^{7}$ Our task is to take up this challenge where the Court has not.

\footnotetext{
${ }^{3}$ Formal case citation, sub C I 3 ("The obligation to respect the law and justice (Art. 20.3) also applies to the observation of the ECHR guarantees as well as the decisions of the European Court of Human Rights within the confines of methodologically justifiable statutory interpretation. The failure to consider a decision of the Court, just as much as a schematic "execution" of the Court's law against prioritary law may constitute a violation of fundamental rights in connection with the command of the Rule of Law." (Translated by Russell Miller)).

${ }^{4}$ Filàrtiga v. Pena-Irala, 630 F.2d 876 (1980), available at: http://homepage.ntlworld.com/jksonc/docs/ filartiga-630F2d876.html; see hereto, e.g., Stephens, Translating Filártiga: A Comparative and International Law Analysis of Domestic Remedies for International Human Rights Violations, 27 YALE J. INT'L L. 1 (2002).

5 Still, the authoritative formula is offered by Jessup, TRANSNATIONAL LAW (1954), 1-16; Scott/Wai, Transnational Governance of Corporate Conduct through the Migration of Human Rights Norms: The Potential of Transnational "Private" Litigation, in: TRANSNATIONAL GOVERNANCE AND CONSTITUTIONALISM 287-319 (JOERGES/SAND/TEUBNER ED. 2004); For an overview of the concept's origin and subsequent development $m y$ "Transnational Law" in: ENCYCLOPEDIA OF COMPARATIVE LAW (JAN SMITS ED.), forthcoming 2005; see already Zumbansen, Piercing the Legal Veil: Commercial Arbitration and Transnational Law, in: 8 EUROPEAN LAW JOURNAL 400-432 (2002).

${ }^{6}$ See only Schepel, Constituting Private Governance Regimes: Standards Bodies in American Law, in: TRANSNATIONAL GOVERNANCE AND CONSTITUTIONALISM 161 (JOERGES/SAND/TEUBNER EDS. 2004).

7 There are proposals in this regard: see, e.g., Starck, Die Rechtswissenschaft in der Zukunft, in: FESTSCHRIFT BROHM 567 (EBERLE/IBLER/LORENZ EDS. 2002), (trusting in the rationality of our "legal methodology“ to select from the influences of Globalization what is worthy); on the other hand, see Kennedy, Two Globalizations of Law and Legal Thought: 1850-1968, in: 36 SUFFOLK L. REV. 631 (2003) (reconstructing the
} 
Against a background of a growing amount of case law, commentary and scholarship in the field of transnational human rights litigation, one of our tasks is to reflect on the ways in which law has been able and might in the future be able to address the different issues raised by this phenomenon. The fact that "movements to bring justice for historical wrongs" 8 have been developing with various dynamics and degrees of success - depending on the evaluation of the outcome points to the intricacy of the whole undertaking. ${ }^{9}$ Comparing the different assessments of the motives, procedures and substantive law; considering the outcome of and the relationship to alternative routes inside or outside of the law and litigation - whether criminal or civil -; we only begin to realize the challenges confronting the law - and to those teaching it. ${ }^{10}$ At the end of this paper, there will follow a brief reflection on the growing difficulty of upholding clear divides in law school curricula between so-called basic, core curriculum courses on the one hand and "international," and comparative subjects on the other. ${ }^{11}$ Before undertaking that discussion, however, this paper presents a tentative approach to understanding the complexity of globalized law. A closer look at transnational law and, in particular, at transnational human rights litigation or transnational civil litigation [TCL] will serve to sketch the ways in which any analysis of the

rise and fall of formalist 'classical legal thought' and the emergence of 'the social' as the subsequently dominating theme in legal theory); while Kennedy's article still holds the promise to extend (in a sequel) to globalized law as such, see for an assessment of 'the social' in transnational civil litigation: Scott/Wai, Transnational Governance of Corporate Conduct through the Migration of Human Rights Norms: The Potential of Transnational "Private" Litigation, in: (JOERGES/SAND/TEUBNER EDS)., supra, note 5, at 294.

${ }^{8}$ Bazyler, WWW.SWISSBANKCLAIMS.COM: The Legality and Morality of the Holocaust-Era Settlement with the Swiss Banks, 25 FORDHAM INT'L L. J. 64-106 (2001), at 64.

9 See, e.g, Reimann, The End of Comparative Law as an autonomous subject, TULANE EUROPEAN AND CIVIL LAW FORUM 49-72 (1996); Valcke, Global Law Teaching, 54 J. Legal Educ. 160-181 (2004).

${ }^{10}$ For an overview of recent examples of such litigative and alternative undertakings, see Bazyler, The Holocaust Restitution Movement in Comparative Perspective, 20 BERKELEY J. INT'L L. 11-44 (2002); Stephens, Translating Filártiga: A Comparative and International Law Analysis of Domestic Remedies for International Human Rights Violations, 27 YALE J. INT'L L. 1-57 (2002); see also the contributions in LETHE'S LAW: Justice, LAW AND ETHICS IN RECONCILIATION (Christodoulidis/VeitCh EDS. 2001). On the impact on law school curricula, see, infra, sub D., and the papers by Arthurs, Poor Canadian Legal Education: So Near to Wall Street, So Far from God, 38 OsGoOde Hall LaW Journal 381 (2000); Valcke, Global Law Teaching, 54 J. LegAL EDUC. 160-181 (2004); Reimann, Taking Globalization Seriously: Michigan Breaks New Ground by Requiring the Study of Transnational Law, 82 MichigAn BAR JOURNAL $52-54$ (2004); Knop, Here and There: International Law in Domestic Courts, 32 N.Y.U. J. INT'L L \& POL. 501-535 (2000); Dorsen, Achieving International Cooperation: N.Y.U.'s Global Law School Program, J. LEGAL EDUC. 332-337 (2001).

11 On the erosion of this boundary, see the references, supra, note 9; see also Reimann, The End of Comparative Law as an autonomous subject, TULANE EUROPEAN AND CIVIL LAW FORUM 49-72 (1996), and Ginsburg, Looking Beyond Our Borders: The Value of a Comparative Perspective in Constitutional Adjudication, 40 IDAHO L. REv. 1-10 (2003), particularly highlighting the relevance of the German Law Journal in this light, id., at 3. 
backgrounds and prospects of TCL is likely to unfold in a fragmentary, opened discourse in which voices and vocabulary from other times ${ }^{12}$ and disciplines ${ }^{13}$ inevitably find their way into legal argument.

\section{Transnational Civil Litigation as a Looking Glass}

The phenomenon of transnational civil litigation [TCL] offers itself as a fruitful instrument through which we can critically assess contemporary aspirations of a globalized law. In the caselaw and scholarship on TCL, we find an abundance of classroom-worthy examples of exhausted doctrinal figures, odd comparisons and weakly reasoned standards, of intricate fusions of law and politics, of theory and myth. ${ }^{14}$ TCL's struggle to gain ground in a world where we must console ourselves with symbolic advances and gains in the light of repeated failures in the courts ${ }^{15}$ presents numerous challenges to legal theorizing that so often self-assuredly dismisses "unknown" or new claims and at the same time remains very skeptical towards an interdisciplinary assessment of legal argument. ${ }^{16}$ Against this background, this paper suggests that drawing analogies between theory building on the international level of legal scholarship and that which is going on within domestic law can help us understand the challenges of globalized law and globalized legal scholarship.

\footnotetext{
12 See only Morgan, Slaughterhouse-Six: Updating the Law of War, in: 5 GERMAN LAW JOURNAL 525-544 (2004), available at: http://www.germanlawjournal.com/pdf/Vol05No05/PDF_Vol_05_No_05_525544_special_issue_Morgan.pdf.

${ }^{13}$ See the "questions" raised by Burt Neuborne towards the end of his 'preliminary reflections': Neuborne, Preliminary Reflections on Aspects of Holocaust-Era Litigation in American Courts, 80 Washington University Law Quarterly 795-834 (2002).

14 See Morgan, supra, note 12; Koh, Separating Myth from Reality About Corporate Responsibility Litigation, 7 JOURNAL OF INTERNATIONAL ECONOMIC LAW 263-274 (2004)

15 See hereto the accounts by Baumgartner, Human Rights and Civil Litigation in United States Courts: The Holocaust-Era Cases, 80 WASH. U. L. QUARTERLY 835-854 (2002); Bazyler, WWW.SWISSBANKCLAIMS.COM: The Legality and Morality of the Holocaust-Era Settlement with the Swiss Banks, 25 FORDHAM INT'L L. J. 64-106 (2001); Neuborne, supra, note 12; Adler/Zumbansen, The Forgetfulness of Noblesse: A Critique of the German Foundation Law Compensating Slave and Forced Laborers of the Third Reich, 39 HARVARD JOURNAL ON LEGISLATION [and in: ZWANGSARBEIT IM DRITTEN REICH: ERINNERUNG UND VERANTWORTUNG / NS FORCED LABOR: REMEMBRANCE AND RESPONSIBILITY 333 (P. ZUMBANSEN ED. 2002)] 1-61 (2002)

${ }^{16}$ See hereto Pal Wrange, Of Power and Justice, in: 4 GERMAN LaW JournaL No. 9 (1 September), 935-962, at 938-9, 945-954, available at http://www.germanlawjournal.com/pdf/Vol04No09/ PDF_Vol_04_No_09_935-962_SI_Wrange.pdf.
} 
These challenges present themselves in contemporary theory building in international and, more precisely, transnational law, meaning the difficult-toembrace field of study of border crossing regulatory, adjudicatory and normative interaction of state and non-state actors. ${ }^{17}$ Transnational law, as more fully conceptualized by Philip Jessup, ${ }^{18}$ and subsequently redefined and reassessed many times, aspires to allow for an observation and explanation of the transformation of individual and collective bodies, "private" or "public," of their actions and of the rules they follow or even produce, through a process of reflexive autonomy from the otherwise state-centeredness of traditional international law. ${ }^{19}$ Indeed, the formula of "transnational law" continues to be more a promise than a descriptive term that would itself already be firmly embedded in mainstream scholarship. One explanation for this might be the previous attempts to define and to defend the transnational against a predominantly state-centred "Westphalian" understanding of public international law. ${ }^{20}$ From this perspective, the world is differentiated into domestic, i.e. intra-state spheres of societal activity, and into international ones, where states, governments and officials interact. ${ }^{21}$ The phenomenon of litigation brought before foreign courts for distant human rights violations, perpetrated by governments or private actors, however, forcefully undermines these categories. While many questions remain regarding the admissibility of such litigation, the numerous attempts to bring instances of past

17 See, hereto, e.g., Slaughter, Judicial Globalization, 40 VIRGINIA JouRNAL OF INTERNATIONAL LAW 11031124 (2000); Schiff Berman, The Globalization of Jurisdiction, 151 U. PA. L. Rev.311-545 (2002).

18 JESSUP, TRANSNATIONAL LAW (1956)

${ }^{19}$ See Scott/Wai, Transnational Governance of Corporate Conduct through the Migration of Human Rights Norms: The Potential of Transnational "Private" Litigation, in: Transnational Governance and Constitutionalism 287-319 (Teubner Ed. 2004), at 289-290; Scott, Translating Torture into Transnational Tort: Conceptual Divides in the Debate on Corporate Accountability for Human Rights Harms, in: TORTURE AS TORT 45-63 (SCOTT ED. 2001), at 52; a brilliant reconstruction of the emergence of transnational legal conceptualizing that consistently draws on the intertwined perspectives of domestic and international law theorizing is provided by Koh, Transnational Legal Process, 75 NeBRASKA LAW REVIEW 181-206 (1996); see also Aceves, Liberalism and International Legal Scholarship: The Pinochet Case and the Move Toward a Universal System of Transnational Law Litigation, 41 Harvard International Law Journal (Harv. Int'l L.J.) 129-184 (2000).

${ }^{20}$ JesSup, TRANSNATIONAl LAW (1956); PANel, The Challenge of Non-State Actors, 92 AMERICAN SOCIETY OF INTERNATIONAL LAW PROCEEDINGS 20-36 (1998); THÜRER, The Emergence of Non-Governmental Organizations and Transnational Enterprises in International Law and the Changing Role of the State, in: NONSTATE ACTORS AS NEW SUBJECTS OF INTERNATIONAL LAW. INTERNATIONAL LAW - FROM THE TRADITIONAL

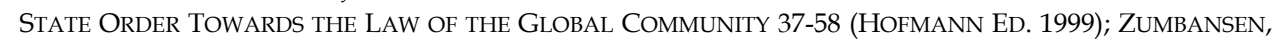
Die vergangene Zukunft des Völkerrechts, 34 KRITISCHE JUSTIZ [KJ] 46-68 (2001).

${ }^{21}$ See, for a concise discussion of the Monist and Dualist approach in International Law, e.g., Rigaux, Hans Kelsen on International Law, in: 9 EUR. J. INT'L L 325 (1998), available at: http://www.ejil.org/journal/Vol9/No2/art6-04.html. 
and distant injustice to courts - ever since the groundbreaking Filàrtiga case in $1980^{22}$ - serve as a testimony of the present challenge. Thus, it would be against this background that we might accommodate ourselves to the use of the term transnational to address and to identify the phenomenon of civil human rights litigation before foreign courts. ${ }^{23}$ Moreover, however, the term transnational captures the ambiguous quality of such litigation in a wider sense. No-one can deny that there are more problematic aspects to such human rights litigation than mere issues of procedural or even substantive law. What becomes obvious in the light of newspaper reporting on cases such as Bouzari24 or the Arar affair in Canada, ${ }^{25}$ is an increasingly widespread discussion, concern and awareness of distant rights violations, regardless of the level of (legal or other) expertise in effectively prosecuting the perpetrators. Whether or not such awareness amounts to a global public sphere, to a global civil society, to a ubiquitous transnational human rights dialogue, or even a constitutionalized sphere of world law, 26 there are certainly strong signs of increased border-crossing activities among private parties and public officials addressing instances of human rights violations worldwide. ${ }^{27}$ One of the pertinent questions then is what role law can play in this regard. Is law's dominion merely the demarcation of fora for litigation or is it the establishment of procedural and substantive rules that allow for a universal treatment of human rights issues? Where and how, between these minimum and maximum scenarios, are we to identify a starting point for an assessment of the role of law?

\footnotetext{
${ }^{22}$ Filartiga v. Pena-Irala, 630 F.2d 876 (U.S. Court of App., 2nd Cir. 30 June 1980). Filàrtiga was brought under the "rarely invoked" (Irving R. Kaufman, Cir.J., id., at 878) ALIEN TORT CLAIMS ACT of 1789 [28 U.S.C.A. § 1350] (available at: http://caselaw.lp.findlaw.com/scripts/ts_search.pl?title=28\&sec=1350). The case recognized federal jurisdiction in cases brought before its Courts for "deliberate torture perpetrated under color of official authority violates universally accepted norms of the international law of human rights, regardless of the nationality of the parties." (Id.) The case set off a wave of cases for human rights violations perpetrated abroad by governments or private entities, see for a concise account Scott, Translating Torture into Transnational Tort: Conceptual Divides in the Debate on Corporate Accountability for Human Rights Harms, in: TORTURE AS TORT 45-63 (SCOTT ED. 2001).

${ }^{23}$ See the concise analysis by Michaels, Three Proceedings of Legal Unification: National, International, Transnational, 96 A.S.I.L. PROCEEDINGS 333-336 (2002).

24 Bouzari v. Iran [2002], O.J. No. 1624 (http://incat.org/projects/bouzari.pdf); http://www. theglobeandmail.com/servlet/story/RTGAM.20041001.wnovogrodsky01/BNStory/Front/.

25 See http://www.cbc.ca/stories/2003/11/24/arar_lawsuit031124; http://www.cbc.ca/news/ background/arar/.

${ }^{26}$ See, e.g., Fischer-Lescano, Die Emergenz der Globalverfassung, in: 63 ZEITSCHRIFT FÜR AUSLÄNDISCHES ÖFFENTLICHES RECHT UND VÖLKERRECHT - HEIDELBERG JOURNAL OF INTERNATIONAL LAW [ZAÖRV], 717760 (2003).

${ }^{27}$ See Safferling, Can Criminal Prosecution be the Answer to massive Human Rights Violations?, in this issue.
} 
II. "To the understanding of transnational legal problems we may then address ourselves"28

The central argument put forward here is that we need to complement the current attempts at widening our conceptual horizon for an adequate treatment of new claims, identities and entities; and a new conceptual horizon for their "translation" 29 into legal language, eventually materializing in an increasingly interdisciplinary exploration of legal claims by other perspectives. ${ }^{30}$ As odd as this might seem in light of the view that many contemporary appearances of "governance without government" suggest that much of our traditional theorizing and modeling is rendered useless, this paper's proposal is to look back to the nation state in order to revisit the ways in which we have learned to speak, to develop, and to fight over political power and government by law in that context. Against this background we shall be able to better discern and confront the challenges that emerge from the ongoing multiplications and fragmentations of legislative and adjudicative sources. ${ }^{31}$ Revisiting central vocabulary of democratic government, such as state, rights, separation of powers, legal process, representation, rule of law, federalism and democracy will allow us to realize the degree to which our learned, tacit understandings continue to inform our contemporary conceptualizing of new claims and new forms of rights as well as their genesis, recognition and enforcement. Consequently, our attention will again have to turn to the actors, now not acknowledged by a realist International Relations perspective which focuses on power, ${ }^{32}$ but nonetheless apparent from a jurisgenerative perspective. Concentrating on the new and manifold ways in which norms are being produced, communicated, recognized and followed, ${ }^{33}$ we shall begin to grasp the complexity of the changing landscape of norm-producing actors.

\footnotetext{
28 Philip JeSsup, TRANSNATIONAL LAW 11 (1956).

29 Scott, Translating Torture into Transnational Tort: Conceptual Divides in the Debate on Corporate Accountability for Human Rights Harms, in: TORTURE AS TORT 45-63 (SCOTT ED. 2001); Zumbansen, Piercing the Legal Veil: Commercial Arbitration and Transnational Law, 8 EUROPEAN LAW JOURNAL 400-432 (2002).

${ }^{30}$ See hereto the contribution by Kemmerer, Like Ancient Beacons: The European Union and the International Criminal Court - Reflections from afar on a Chapter of European Foreign Policy, in this issue.

31 See, e.g., Romano, The Proliferation of International Judicial Bodies: The Pieces of the Puzzle, 31 New York University Journal of International Law and Policy (N.Y.U. J. Int'l L. \& Pol.) $709-751$ (1999).

32 See, in this context, Baumgartner, Human Rights and Civil Litigation in United States Courts: The Holocaust-Era Cases, 80 WASH. U. L. QUARTERLY 835-854 (2002), 837.

${ }^{33}$ Very insightful Zürn, Sovereignty and Law in a Denationalised World, in: Rules and Networks. The Legal Culture of Global Business Transactions 39-71 (GESSNER/ APPELBAUM/FELSTINER EDS. 2001).
} 


\section{B. The Globalization of Regulatory Theory}

With regard to changes in public governance sub verbis privatization, selfregulation, public-private partnerships and private ordering, we need to consider the following elements for a better understanding of the transformation of law:

i) Proliferation of arenas and levels of regulation (Litigation, treaty law, organizations, government agency networks)

ii) Alternative routes of criminal prosecution and of civil litigation as reflected in the troubled creation of the International Criminal Court on the one hand and the (no less troubled experiences of) transnational civil human rights litigation on the other

iii) Changes in the modes of regulation (contracting, resort to "soft law" and recommendations, best practice codes, "conventions")

\section{I) Institutions and Processes}

The suggestion put forward here is that an unrealized wealth of interaction and of its normative foundation can be found in the zones between these different disciplinary approaches. They are, however, characterized - much as are the utopian claims of the $20^{\text {th }}$ Century for the regulatory welfare state - by a structural and normative exhaustion. ${ }^{34}$ The current state of theorizing within these schools of thought within the respective disciplines - economics, political science, sociology and law (e.g. comparative law) - reflect overarching attempts at extending the applicability and theoretical reach of the disciplines' own instruments. Each discipline betrays an internal struggle to adapt to two main transformations in the social sphere. These changes touch upon the actors with which these theories are concerned and the actions performed by these actors. The proliferation of actors in the domestic and the international scene informs the theorizing on current changes in methodology in light of globalization and privatization. The erosion of traditional standards of identifying and assessing actors is paralleled by an ever increasing differentiation of actions performed by these actors. Ultimately, concepts such as regulatory intervention and societal self-regulation that were modeled on a clear boundary between the state and the market, between public and private, eventually fail to capture the hybridization of contemporary public, private, quasipublic actors and their actions.

For example, law and legal science engage in a painful adaptation of their instruments and vocabulary to a multifaceted world of political actors, but this is

\footnotetext{
${ }^{34}$ Habermas, Die Krise des Wohlfahrtsstaates und die Erschöpfung utopischer Energien, in: ibid., DIE NEUE UNÜBERSICHTLICHKEIT 141-163 (1985).
} 
often done by resorting to the very notions that now seem to have lost so much of their validity. The fate of the attempts to succeed in the sphere of transnational civil litigation very much reflect the resistance from legal science to accept the erosion of boundaries and of the foundations for an authoritative take on the shaping of law for a certain constituency. At the same time, TCL underlines the law's confines and the need to put these to a constant test both practically and normatively. The degree to which TCL (e.g., against multinational corporations ${ }^{35}$ ) serves to expose the embeddedness of "private" enterprises in a web of public and private regulation on a domestic and international level is reveals the public function of private litigation. Thus, TCL reemphasizes the findings of the Legal Realists and their critique of private power. ${ }^{36}$

\section{II) The Law}

Under the pressure of transforming state functions, the demise (and the possible reconception) of the regulatory welfare state of the Western World in the 20th Century has had a strong impact on the role and function of law itself. This has led to an important inquiry into the nature of the law long before the contemporary findings of a seemingly ubiquitous emergence of "soft law." In the 1970s and 1980s, the keywords characterizing this critique included:

- $\quad$ juridification $(\mathrm{I})^{37}$

- $\quad$ crisis of regulatory law ${ }^{38}$

- parliamentary delegation of law making powers to branches of the executive, but also to private parties ${ }^{39}$

\footnotetext{
35 Blumberg, Asserting Human Rights Against Multinational Corporations under United States Law: Conceptual and Procedural Problems, 50 American Journal of Comparative Law 493-529 (2002); Deva, UN's Human Rights Norms for transnational corporations and other business enterprises: an imperfect step in the right direction?, 10 ILSA JOURNAL OF INTERNATIONAL AND COMPARATIVE LAW 493-523 (2004).

36 Pound, The New Feudalism, 16 American Bar Association Journal 553-558 [also in: The New Feudal System, COMMERCIAL LAW JOURNAL 397-403 35 (1930), 397-403] (1932)

37 Wiethölter, Privatrecht als Gesellschaftstheorie?, in: FUNKTIONSWANDEL DER PRIVATRECHTSINSTITUTIONEN. FESTSChrift FÜr LUDWIG RAISER ZUM 70. GEbURTSTAG 645-695 (BAUR/ESSER/KÜBLER/STEINDORFF EDS. 1974).

38 Teubner, Juridification - Concepts, Aspects, Limits, Solutions, in: JURIDIFICATION OF SOCIAL SPHEREs 3-48 (TEUBNER ED. 1987).

39 Landis, The Administrative Process (1938); but see Kirchhof, Demokratie ohne parlamentarische Gesetzgebung?, 54 NEUE JURISTISCHE WOCHENSCHRIFT (NJW) 1332-1334 (2001); Baums, Interview: Reforming German Corporate Governance: Inside a Law Making Process of a very new nature, 2 GERMAN LAW
} 
These keywords point to theoretical assessments focusing on:

- $\quad$ post-regulatory law ${ }^{40}$

- reflexive law ${ }^{41}$

- $\quad$ law of the post-interventionist state ${ }^{42}$

- $\quad$ societal self-regulation/private interest government/private law making 43

Today's assessments build on this work. The following phenomena are discussed and are of importance for our assessment of any normative dimension of regulatory interaction:

- $\quad$ horizontal effect of constitutional law, ${ }^{44}$

- $\quad$ constitutional analogies ${ }^{45}$ and comparative legal semiotics, ${ }^{46}$

- $\quad$ migration of human rights standards, ${ }^{47}$

- neo-spontaneous law, 48

JOURNAL No. 12 (16 July 2001), available at: http://www.germanlawjournal.com/past_issues. php?id=43.

40 Ladeur, The Theory of Autopoiesis as an Approach to a Better Understanding of Postmodern Law, EUI Working Paper Law No. 99/3 (1999).

${ }^{41}$ Teubner, Reflexives Recht, 68 ARSP 13-59 (1982).

42 Vesting, Zwischen Gewährleistungsstaat und Minimalstaat: $Z u$ den veränderten Bedingungen der Bewältigung öffentlicher Aufgaben in der 'Informations- oder Wissensgesellschaft', in: VERWALTUNGSRECHT IN DER INFORMATIONSGESELLSCHAFT 101-131 (HOFFMANN-RIEM/SCHMIDT-ASSMANN ED. 2000); Frankenberg, Why Care? - The Trouble with Social Rights, 17 CARDOZO LAW REVIEW 1365-1390 (1996); Zumbansen, Quod Omnes Tangit: Globalization, Welfare Regimes and Entitlements, in: The Welfare State, Globalization, and International Law 135-173 (Benvenisti/Nolte Ed. 2003).

${ }^{43}$ Black, Constitutionalising Self-Regulation, 59 MOdERn LAW REVIEW 24 (1996).

${ }^{44}$ Gardbaum, The "Horizontal Effect" of Constitutional Rights, 102 Michigan LAW REvieW 387-459 (2003); Teubner, Ein Fall struktureller Korruption? Die Familienbürgschaft in der Kollision unverträglicher Handlungslogiken (BVerfGE 89, 214ff.), 83 KRITISCHE VIERTELJAHRESSCHRIFT FÜR GESETZGEBUNG UND RECHTSWISSENSCHAFT 388-404 (2000); Zumbansen, Public Values, Private Contracts and the Colliding Worlds of Family and Market, 11 FEMINIST LEGAL STUDIES 73-87 (2003).

45 Helfer, Constitutional Analogies in the International Legal System, LoY. L. A. L. REV. 193-236 (2003); Choudhry, The Lochner Era and Comparative Constitutionalism, UNIVERSITY OF TORONTO FACULTY OF LAW, Public LAW AND LegAl THeORY RESEARCH PAPER No. 02-22 (2002)

${ }^{46}$ Grossfeld, CyberCorporation Law - Comparative Legal Semiotics/Comparative Legal Logistics, 35 THE INTERNATIONAL LAWYER 1405-1425 (2001)

${ }^{47}$ Scott/Wai, supra, note 5 .

${ }^{48}$ Teubner, Globale Privatregimes: Neo-spontanes Recht und duale Sozialverfassungen in der Weltgesellschaft, in: ZUR AUTONOMIE DES INDIVIDUUMS. LIBER AMICORUM SPIROS SiMITIS 437-453 (SIMON/WEISS EDS. 2000) 
- juridification (II). ${ }^{49}$

If we compare this narrative, to the narrative offered by Harold Koh in 1996 of the development of U.S. American legal theory, ${ }^{50}$ we begin to realize the importance of seeing the connections between developments of comparative constitutional law ${ }^{51}$ against a troubled comparative law science ${ }^{52}$ and the intricate exploration of comparative law in private international law. ${ }^{53}$ These connections, however, must be considered alongside the national discourses on legal development and the international(ist) ones. Furthermore, we may recognize the otherwise hidden and unrealized implications of ceaseless assessments of the law's role in struggles over sovereignty, territory, and limits to litigation. Koh masterfully and very sensibly sketches the background of ideas and events driving the development of US legal culture. In fact, it is only against such a rich reflective background that we can begin to understand what is at stake when we engage in discussions over the merits and the backdrops of TCL. The Political Economy of Jurisdictional Competence for human rights litigation, then, literally unfolds in a competition of different cultural worlds.

\section{Transnational Law}

There is still much skepticism against what is believed to be a premature dismissal of the state in favor of models of a "global civil society" 54 or an emerging "global Bukowina" 55 - even among those scholars who devote their work to a critical investigation of the new forms of governance beyond the nation state. What this

\footnotetext{
49 Wiethölter, Recht-Fertigungen eines Gesellschafts-Rechts, in: RECHTSVERFASSUNGSRECHT. RECHTFerTigung ZWISCHEN PRIVATRECHTSDOGMATIK UND GESELlSCHAFTSTHEORIE 11-22 (JOERGES/TeUbNER EDS. 2003)

${ }^{50}$ Koh, Transnational Legal Process, 75 NeBRASKA LAW REVIEW 181-206 (1996).

${ }^{51}$ See, e.g., Choudhry, The Lochner Era and Comparative Constitutionalism, University of Toronto Faculty of Law, Public Law and Legal Theory Research Paper No. 02-22 (2002)

${ }^{52}$ See the brilliant assessment by Michaels, Im Westen nichts Neues?, 66 RABELSZ 97-115 (2003).

53 Wai, Transnational Liftoff and Juridical Touchdown: The Regulatory Function of Private International Law in an Era of Globalization, 40 COLUMBIA JOURNAL OF TRANSNATIONAL LAW 209-274 (2002).

${ }^{54}$ KALDOR, GLOBAL Civil SOCIETY: AN ANSWER TO WAR 2003); Anheier/Kaldor/Glasius, Global Civil Society in an Era of Regressive Globalisation: The State of Global Civil Society in 2003, in: Global Civil Society Yearbook 2003 3-33 (Anheier/Kaldor/Glasius Ed. 2003),

55 Teubner, 'Global Bukowina': Legal Pluralism in the World Society, in: Global LAW Without A STATE 3-28 (TEUBNER ED. 1997).
} 
skepticism seems to express most clearly, however, is a continuing discomfort with the ways in which law has been used and continues to be used for (making sense of) global governance. Beyond battles over the waning and waxing of nation states in the process of globalization, there appears to be a strong consensus that the state, even if in changed form, continues to be much more than merely an artifact in international law and the development of legal theory. ${ }^{56}$ Indeed, the state is widely regarded to be undergoing dramatic changes with regard to its regulatory capacities and, more importantly, its regulatory forms and instruments. ${ }^{.7}$ In this light, we need to reflect on our capacities and instruments to bring law to bear on these changes. But, how are we to do this? Only a parallel view of both of the governance experiences made within the nation-state and those arising from the "post-national" constellation ${ }^{58}$ can offer explanations for our present difficulties in addressing the exhaustion of legal norms. Only by creating a dialogue between regulatory law and lawyers of the nation state and international lawyers contemplating the normative weight of international legal norms and the globalization challenges to a state-centred and law-based understanding of political order can we hope to understand the present situation. It is, in fact, only against the background of such a domestic-international dialogue that we may understand the various legal, political, cultural and historical aspects implicated in transnational human rights litigation. Just as the debate over "humanitarian intervention" that arose with the Kosovo War in 1999 was hardly a discussion only among international lawyers and even less one only concerning international law, ${ }^{59}$ the discussion about "international law in domestic courts" 60 is a much more general

\footnotetext{
${ }^{56}$ See only the assessment by Schneiderman, Investment Rules and the New Constitutionalism, 25 LAW \& SOC INQUIRY 757-783 (2000).

57 See, e.g., from the German constitutional perspective, Di FABIO, DER VERFASSUNGSSTAAT IN DER WELTGESELLSCHAFT 2001); Hobe, Der offene Verfassungsstaat zwischen Souveränität und Interdependenz. Eine Studie zur Wandlung des deutschen Staatsbegriffs der deutschsprachigen Staatslehre im Kontext internationaler institutionalisierter Kooperation 1998); Frankenberg, Shifting Boundaries: The Private, the Public, and the Welfare State, in: The Mixed Economy of Social Welfare 7294 (Katz/Sachße Ed. 1996); see also Hobson/Ramesh, Globalisation Makes of States What States Make of It: Between Agency and Structure in the State/Globalisation Debate, 7 New POLITICAL ECONOMY 5-22 (2002).

58 Very insightful Habermas, Die postnationale Konstellation und die Zukunft der Demokratie, in: ibid, Die postnationale Konstellation (1998) 91-169; see now the very outspoken return to a critical theory of democracy within the nation-state and its lessons for the 'post-national constellation' by Habermas, Hat die Konstitutionalisierung des Völkerrechts noch eine Chance?, in: ibid, Der gespaltene Westen (2004) 113-193. 59 See only Koskenniemi, 'The Lady Doth Protest Too Much'. Kosovo, and the Turn to Ethics in International
Law, 65 Modern Law Review 159-175 (2002); ibid., Book Review - Giovanna Boradori (ed.), Philosophy in a
Time of Terror. Dialogues with Jürgen Habermas and Jacques Derrida (2003), in : 4 GERMAN LAW
JouRNAL No.10 (1 October 2003), 1087-1094, available at: http://www.germanlawjournal.com/
pdf/Vol04No10/PDF_Vol_04_No_10_1087-1094_Legal_Culture_Koskenniemi.pdf.
}

${ }^{60}$ Knop, Here and There: International Law in Domestic Courts, 32 N.Y.U. J. INT'L L \& POL. 501-535 (2000). 
one. It is a discussion over the merits and scope of transnational human rights litigation, over sovereignty issues of defendant states, corporations or individuals, and over the viability of addressing not only distant but also past injustice by way of litigation. Seen in this light, we can cut through the complex maze of territoriality issues, procedural obstacles, "diplomacy," 61 immunities and statutes of limitations and, instead, perceive of the nascence of transnational civil litigation as of a valuable opportunity to reevaluate our understanding of regulatory law as such.

\section{Law and other Discourses}

\section{The State}

As suggested, such dialogue can be started by tracing the use of central terms and concepts both on the domestic and the transnational level. The "state" is one such concept. It remains heavily implicated in the growth and further differentiation of transnational human rights litigation, one more recent example of this being the fate of the Holocaust-Era litigation in US American and German courts. ${ }^{62}$ This litigation was mainly pursued during the second half of the 1990s and was characterized by a mesmerizing flourishing of public and private actors that participated and accompanied the proceedings. Throughout this litigation the state played a decisive role. While, by now, there are numerous accounts on the role of the state in this process, in particular of governments and their diplomats involved in negotiations accompanying and eventually bringing an end to litigation but, nevertheless, obtaining pecuniary compensation, 63 this diplomatic end to much of the Holocaust litigation ${ }^{64}$ fails to fully illuminate the meaning of the state's presence

\footnotetext{
${ }^{61}$ See, e.g., Neuborne, Preliminary Reflections on Aspects of Holocaust-Era Litigation in American Courts, 80 Washington University Law Quarterly 795-834 (2002), at 795; see also Eizenstat, Imperfect Justice. Looted Assets, Slave Labor, and the Unfinished Business of World War II (2003).

${ }^{62}$ See the overview by Bazyler, WWW.SWISSBANKCLAIMS.COM: The Legality and Morality of the Holocaust-Era Settlement with the Swiss Banks, 25 FordHAM INT'L L. J. 64-106 (2001); Neuborne, Preliminary Reflections on Aspects of Holocaust-Era Litigation in American Courts, 80 Washington University Law Quarterly 795-834 (2002); in contrast to these overly sympathetic accounts (and their appraisal of US legal litigation culture), see the comments by Baumgartner, Human Rights and Civil Litigation in United States Courts: The Holocaust-Era Cases, 80 WASH. U. L. QUARTERLY 835-854 (2002), identifying the political pressure exerted on the litigants.

${ }^{63}$ See hereto, e.g., Bazyler, WWW.SWISSBANKCLAIMS.COM: The Legality and Morality of the HolocaustEra Settlement with the Swiss Banks, 25 FORDHAM INT'L L. J. 64-106 (2001), at 64, who concentrates on routes to monetary compensation when thinking of other "movements aiming to bring justice for historical wrongs".

${ }^{64}$ Mainly for the recompensation of never paid out so-called dormant bank accounts in Swiss Banks, insurance claims as well as for looted assets and slave labor.
} 
in these cases. While a wide consensus recognizes the merit of international diplomacy to short-cut possibly never-ending and ultimately failing litigation efforts in favor of fund-creations and lump-sum settlements, ${ }^{65}$ this view tells us nothing about the continuity of state politics in the general administration of the litigation process from an historical perspective. While diplomacy is offered as a savior to allegedly hopeless court proceedings, we learn nothing about the history of that very diplomacy that prevented both court proceedings and compensation as well as recognition of the perpetrators' crimes - since the time the crimes occurred. 66

But, the view depends on the glasses we are wearing. Seen through the lens of the applicable law, the history of holocaust litigation had largely been one of failure. ${ }^{67}$ Seen through the lens of international politics, the rising class-action proceedings in the 1990s had to be treated not as legal issues, but as issues of international politics, diplomacy, and bi- and multilateral agreement. On the domestic level in Germany, what arose was a complex interplay of private and public, eventually legislative initiative to create a compensation fund to end all litigation. Already during its conceptualization and its creation process, courts began to refer to this "political venue" that would ultimately preclude a court hearing a related case. 68 Internationally, Berlin and Washington reached an agreement by which the U.S. government would issue a so-called Statement of interest to its judiciary pointing to the political resolution of the compensation claims that were still being brought before U.S. courts. The German parliament waited until a Statement of interest was

\footnotetext{
${ }^{65}$ Bazyler, The Holocaust Restitution Movement in Comparative Perspective, 20 BERKELEY J. INT'L L. 11-44 (2002); Neuborne, Preliminary Reflections on Aspects of Holocaust-Era Litigation in American Courts, 80 Washington University Law Quarterly 795-834 (2002).

${ }^{66}$ Adler/Zumbansen, The Forgetfulness of Noblesse: A Critique of the German Foundation Law Compensating Slave and Forced Laborers of the Third Reich, 39 HARVARD JOURNAL ON LEGISLATION [and in: ZWANGSARBEIT IM DRITTEN ReICH: ERINNERUNG UND VERANTWORTUNG / NS FORCED LABOR: REMEMBRANCE AND RESPONSIBILITY 333 (P. ZuMBANSEN ED. 2002)] 1-61 (2002); BENJAMIN B. FERENCZ, LesS THAN SLAVES: JEWISH FORCED LABOR AND THE QUEST FOR COMPENSATION (1979); UlRICH HERBERT, FREMDARBEITER: Politik Und Praxis Des "Auslander-EINSATZES" In Der KriEgswirtschaft Des DritTEN Reiches (2d Ed. 1999); Wolfgang Benz, Zwangsarbeit im nationalsozialistischen Staat, 16 DACHAUER HEFTE 3, 3-17 (2000).

${ }^{67}$ Vagts/Murray, Litigating the Nazi Labor Claims: The Path Not Taken, 43 Harvard International Law Journal (Harv. Int'l L.J.) 503-530 (2002).

${ }^{68}$ For a critique of this case law, see Safferling/Zumbansen, Iura novit curia: Rechtsanspruch auf Entschädigung für Zwangsarbeit im Nationalsozialismus, in: JURISTISCHE RUNDSCHAU 6-11 (2002) [reprinted in: ZWANGSARbEIT IM DRITTEN REICH: ERINNERUNG UND VERANTWORTUNG / NS FORCED LABOR: REMEMBRANCE AND RESPONSIBILITY (P. ZUMBANSEN ED. 2002)]; from the U.S. case law, see in particular Burger-Fischer v. Degussa AG, 65 F. Supp. 2d 248, $279-81$ (D.N.J. 1999); see Iwanowa v. Ford Motor Co., 67 F. Supp. 2d 424 (D.N.J. 1999).
} 
issued before declaring "legal peace" in May 2001, thereby clearing the way for the German Foundation "Remembrance, Responsibility, and the Future" to pay individual compensation to former Forced or Slave Laborers under the Third Reich. 69

\section{The Deafening Noise of Litigation}

Searching for explanations of this development one is confronted with a complex situation of conflicting interests. A reading of contemporary assessments of the Holocaust-Era Litigation reveals a strong predominance of the participants' focus on monetary compensation. ${ }^{70}$ As mentioned already, while there is certainly much

${ }^{69}$ See Roger Cohen, Last Chapter: Berlin to Pay Slave Workers Held by Nazis, N.Y. TIMES, May 31, 2001, at A7. The Foundation began making payments on June 19, 2001. See Stephanie Flanders, Payments Begin for Laborers Forced to Work for the Nazis, N.Y. TIMES, June 20, 2001, at A10. See for an account of this development, Adler/Zumbansen, supra, note 54. Note: At the time the Foundation grew out of a German industry wide initiative to create a compensation fund to end class action suits for forced labor recompensation, the present author and his collaborator, Libby Adler, envisioned working together on the litigation and the Foundation with a particular focus on the regulatory aspects of the Foundation. Thus, our original focus was the changing face of public services and the emerging phenomena of 'private ordering' and societal self-regulation. We therefore aimed at exploring the relevance of private law theory within new forms of public service delivery and delegations of public duties (and powers) to private actors. The Foundation offered itself as a perfect instance where a regulatory function, while clearly demarcated as public in nature, had been transferred upon several private actors, the so-called partner organizations responsible for the assessment and the compensation of the claims. The choice of studying the litigation and the Foundation from that angle proved to be one that would eventually guide and inform the authors' further outlook on law and on their work in general in the future. Every aspect of our research and of our teaching a seminar to a group of German and foreign LL.B. and graduate students in Germany, accompanied by the testimony of direct participants in the post-war restitution efforts, the recent class action litigation in American courts, and the contemporary creation and administration of the Foundation, lead to a whole chain of further questions regarding, ultimately, law's role in bringing past injustice before a judicial forum. Thus, the fate of the litigants as well as of those that fought with or against them became deeply intertwined with issues regarding the adjudication of past wrongs, the purpose and ultimate merit of judicial treatment of claims for compensation, recognition and acknowledgment, the importance of establishing legal responsibility compared with otherwise motivated and comparatively easily accepted "moral", "historical" or "political" responsibility, as documented in the preamble of the Foundation law (http://www.stiftung-evz.de/). But, increasingly, law's boundaries became porous and law's demarcation from ubiquitous discourses on reconciliation, societal memory and confronting 'darker legacies' proved ever more difficult.

70 Neuborne, Preliminary Reflections on Aspects of Holocaust-Era Litigation in American Courts, 80 Washington University Law Quarterly 795-834 (2002); Bazyler, WWW.SWISSBANKCLAIMS.COM: The Legality and Morality of the Holocaust-Era Settlement with the Swiss Banks, 25 FORDHAM INT'L L. J. 64-106 (2001); see hereto Niethammer, Beschädigte Gerechtigkeit - Entschädigung von Zwangsarbeitern als Paradigma, in: ZWANGSARBEIT IM DRITTEN REICH: ERINNERUNG UND VERANTWORTUNG. NS-ForCED LABOR: REMEMBRANCE AND RESPONSIBILITY. ZEITHISTORISCHE UND JURISTISCHE BETRACHTUNGEN/HISTORICAL AND LEGAL OBSERVATIONS 259-276 (ZUMBANSEN ED. 2002), pointing to the other dimensions of recognition of past injustice. 
awareness of other forms of confronting past injustice, ${ }^{71}$ perhaps the extremely difficult struggle over compensation for former Nazi-victims pushed the fight for monetary compensation to the forefront. This view still seems to dominate the current discussion, at least in those places where the Holocaust litigation is taken as a possible example of a successful battle for the recognition of injustice..$^{72}$ Ultimately, every case brought before a court raises the (eventually unanswered) question of what the plaintiff actually aspired to get out of the proceeding at the end of the day. ${ }^{73}$ What seems to be a pressing need in light of the ubiquitous uneasiness about the outcomes of the litigation (even where a settlement marks the end of what started as a fight for the recognition of legal responsibility) is, to begin with, a clarification of instances and competences. Examples are numerous, and the trickiness of examples resides in their blocking our view for alternative models. "Nuremberg" thus becomes a chiffre that influences the debate over such different institutions as the ICC, the Yugoslavia Tribunal (ICTY) but also the newly formed Iraqi Special Tribunal (IST) ${ }^{74}$ The state-centeredness of international law becomes strikingly apparent as we assess the chances of the named institutions to bring about reconciliation (not in the least because each of these examples, from Nuremberg to Bagh$\mathrm{dad}$, is more or less possessed of the state).

One level below, we find the same conflict of institutions, instances, and competences. The public debate that was spurred in Germany after the already mentioned class action suits had been brought against German companies before US courts provides a contemporary example of the manifold dangers confronting a societal discourse of reconciliation once the law comes into play. As a textbook example itself for the contemporary hybridization of forms of governance, the Foundation "Remembrance, Responsibility and the Future" grew out of a legal threat and simultaneously did away with the legal dimension of the conflict by reformulating the issue as one of remembrance and of political, historical and moral, albeit not

\footnotetext{
${ }^{71}$ See, e.g., Miller, Much Ado, But Nothing: California's New World War II Slave Labor Law Statute Of Limitations And Its Place In The Increasingly Futile Effort To Obtain Compensation From American Courts, 23 WHITTIER LAW REVIEW 121-136 (2002), reprinted in: ZWANGSARBEIT IM DRITTEN REICH: ERINNERUNG UND VERANTWORTUNG. NS-FORCED LABOR: REMEMBRANCE AND RESPONSIBILITY. ZEITHISTORISCHE UND JURISTISCHE BETRACHTUNGEN/HISTORICAL AND LEGAL OBSERVATIONS (ZUMBANSEN ED. 2002).

72 See hereto, e.g., Neuborne, Preliminary Reflections on Aspects of Holocaust-Era Litigation in American Courts, 80 Washington University Law Quarterly 795-834 (2002); Bazyler, The Holocaust Restitution Movement in Comparative Perspective, 20 BERKELEY J. INT'L L. 11-44 (2002); Miller, Reconceiving Reparations: Multiple Strategies in the Reparations Debate, 24 BOSTON COLLEGE THIRD WORLD LAW JOURNAL 45-79 (2004).

${ }^{73}$ See, on the limits of law (also) in that respect, Goodwin, White Knights On Chargers: Using The US Approach To Promote Roma Rights In Europe?, in this issue.

${ }^{74}$ See, hereto, the analysis by Miller, in: MSU-DCL J. INT'L L. 2004, forthcoming.
} 
legal responsibility. The special character of the German Foundation, with its 5 Billion Euro budget, half funded by German industry and half by the Federal Government, lay in the novel legal basis that provided both for its public creation by an act of Parliament and for the private administration of the actual Foundation work, i.e. the administration of claims brought by former victims or their heirs from all over the world, assessed and carried out by seven private "partner organizations" in countries in Europe and the U.S.. The creation of the Foundation sparked a renewed wide-reaching public interest not only in the tragically long-ignored fate of those who had labored and died in underground factories and other war-industry activities, but also ignited an important discussion in the disciplines of law, political science and history about the ways in which past injustices can be remembered and addressed. Ten years after German reunification and fifty years after the end of the National Socialist regime, the intensive work on the Foundation called into public consciousness the intricacies and fallacies involved with "addressing" a nation's history.

Today, with a number of monographs on this process and on the Foundation, an overwhelming number of scholarly articles, and an ongoing civil society discourse over local archives for forced laborers in thousands of German communities, the question of the role of law might seem superfluous. Society seems to have taken care of the problem, and the Foundation did eventually begin distributing funds to a population of rapidly dying survivors. Yet, this remains entirely unsatisfying. Indeed, the very process of the Foundation's intervention, replacing and ending all attempts at litigation by concrete claimaints before a public forum, raises significant questions as to the role of law. Seen from this angle, the Foundation is but an example through which to explore the role and function of law in such a politically overheated and polemically congested context. While the Foundation (and the funds it distributed, and is still distributing, in exchange for the renunciation of each claimant of any future litigation for compensation in connection with his or her historical fate ${ }^{75}$ ) presented itself as a truly absurd inadequacy of a publicprivate fund to compensate the by-then-rapidly-dying victims and their heirs for the crimes committed against them, the role of the law is almost untraceable. In the eyes of the public, the tedious technicality of questions of statute of limitations, forum non conveniens, contract or tort, individual responsibility, international treaty law and political question doctrine was adequately replaced by a Foundation that would not only be able to provide speedy compensation (as compared to lengthy processes before courts) but, more importantly, provide an allegedly more dignified forum through which to remember and to honor this dark past. While the media

${ }^{75}$ See Section 16 No. 2 of the Foundation Law of 2 August 2000, available at: http://www.stiftungevz.de/. 
reported on the transatlantic negotiations and the numerous and eventually successful attempts by German industry representatives to present their participation in the fund as a moral and political, but not as a legal, recognition of their involvement in the murderous labor industry of the Third Reich, ${ }^{76}$ future research ought to reach beneath this layer of justification.

\section{E. Conclusion, or What is the Matter with Legal Education?}

The above might already have helped to illuminate the degree to which transnational human rights litigation, transjudicial communications and constitutional "borrowing," 77 "constitutional analogies,"78 and the "proliferation of international judicial bodies"79 have long ceased to be of concern only to those working in international law. Any assessment of current developments in core fields of a law school curriculum will inevitably be informed by outside influences of international, transnational and comparative law. 80 While this insight is beginning to take hold in curriculum reform committees everywhere, ${ }^{81}$ it is, however, still a long way to bridge the gap between the mostly traditional canon of First Year Courses and the crème de la crème curriculum specializations that are offered here and there. ${ }^{82}$ As the norm, we find an overwhelming commitment to a First Year, straight- forward legal education in Contracts, Torts and Civil Procedure

\footnotetext{
76 See, e.g., http://www.hagalil.com/archiv/99/11/gerecht.htm; http://www.zeit.de/archiv/2000/20/ 200020.kolumne.xml.

77 Slaughter, A Typology of Transjudicial Communications, 29 UNIVERSITY OF RICHMOND LAW REVIEW 99-137 (1994); see also ibid., A NEW WORLD ORDER (2004), for the reference to the Supreme Court's comparative perspective in Lawrence $v$. Texas (2003).

${ }^{78}$ Helfer, Constitutional Analogies in the International Legal System, Loy. L. A. L. Rev. 193-236 (2003).

79 Romano, The Proliferation of International Judicial Bodies: The Pieces of the Puzzle, 31 New York University Journal of International Law and Policy (N.Y.U. J. Int'l L. \& Pol.) 709-751 (1999); Alford, The Proliferation of International Courts and Tribunals: International Adjudication in Ascendance, 94 American Society of International Law Proceedings 160-165 (2000).

80 This is the basic motivation for the creation of the ICT (International - Transnational - Comparative) Curriculum Stream at Osgoode Hall Law School at York University, a two-year program that allows for a specialization in the named larger disciplinary fields with a strong focus on the national-international 'interface' as students are invited to reflect on the interpenetration of globalized fields of legal doctrine: http://www.yorku.ca/osgoode/streams/\#ict.
}

${ }^{81}$ Ongoing Comparative Curriculum Overview Study at Osgoode Hall Law School, York University, on file with author.

82 See, e.g., from a student's perspective, Carlson, Why Slavery Reparations are Good for Civil Procedure Class, 47 St. Louis U. L. J. 139-147 (2003). 
etc. and, ensuing, a more or (usually) less directed course of upper year studies, allegedly permitting students' autonomous selection of their course menu with a view towards possibly developing distinct avenues of employment. In the meantime, the relationship between the national and the international remains as insufficiently theorized (let alone taught) as that between theory and doctrine. The longstanding inquietude in the latter about whether to throw in a mandatory theory course at the beginning or in the middle of the core curriculum still lingers just as painfully as that regarding the permeation of the law school curriculum with comparative and "international" concepts and ideas. Currently, the governing rules (and fears) of legal education seem to allow for very little reflection on either the structural transformations or the international/comparative dimensions of ongoing changes in administrative or constitutional law, in contract or corporate law, criminal law or civil procedure. ${ }^{83}$

This assessment is likely to leave those teachers unimpressed who find themselves regularly burdened with one or more sections of First Year core curriculum courses. Expectedly, they will point out the importance of providing the students with a solid foundation in the main fields of law. In addition, they are likely to mention the incessantly growing amount of substantive and procedural law that stands in brutal contrast to the crucially limited time that is available during the bref séjour at law school. Thus, the answer as well as - often enough - the resignative end of many reformist initiatives has been to leave the core more or less untouched; a steadfast commitment to teaching the students in minimal time the fundamental rules of substantive and procedural law in order to adequately equip them for practice prevails.

In contrast then, there might be some very sophisticated and often densely structured (i.e. too many classes) Upper Year program supposedly allowing the student to intensify and to deepen his or her knowledge and expertise in a wider field of concentrated study. Certainly, where the Upper Year programs often lack in coherence and philosophy, the First Year curriculum is flawed as well. In light of the fast growing amount of law and its dynamic differentiation, even the core doctrine has to be taught in a highly selective fashion. This is certainly not remedied by pointing to the alleged scholarly maturity of Anglo-American law students who gain the J.D. or LL.B. through a "Second Degree" Course of Study, ${ }^{84}$

83 Arthurs, Poor Canadian Legal Education: So Near to Wall Street, So Far from God, 38 OsGoOde Hall LAW JOURNAL 381 (2000); Wiethölter, Die Wirtschaftspraxis als Rechtsquelle, in: DAS RECHTSWESEN - LENKER ODER SPIEGEL DER GESELLSCHAFT? 165-185 (BOCKELMANN ED. 1971).

${ }^{84}$ The same applies, however, certainly in jurisdictions where law is a so-called First Degree of study, such as Germany or France; see Windel, Scheinspezialisierung und Verzettelung als mögliche Folgen der Juristenausbildungsreform, JURA 79-82 (2003). 
as even an excellent undergraduate degree in political science or biology is by no means a guarantee for a necessarily curious and critical attitude towards the law.

At the same time, faculty teaching First Year courses in Europe or in North America will want to protect the virtual minimum of form and substance in First Year against even further curtailing and optional curriculum design in order to guarantee some form of common comparative ground in legal education within a competitive educational and professional training environment. So, with negligence and fear reigning in contracts and torts education, the fancy stuff is supposed to happen in the Second and Third Years. It is only here, and only at some schools, that the law student might learn about the various international dimensions and comparative influences of the law he or she is in the process of learning. Certainly, while Jurisprudence, Public International Law and Comparative Law can be selected in the upper years, the First Year subjects will appear even more merely "basic," "necessary," and "doctrinal." To the student, then, who specializes in Commercial, Corporate and Securities Law, law school will most likely end without that student having to confront, him-/herself, the grounds for a choice of arguments and assessments. Meanwhile, during law school, the gap widens considerably between these odd creatures who structure their Upper Year curriculum around theory, Indigenous Law, Comparative or International Law and those who move directly from Contracts to Torts to Corporate and Securities on to Bar School.

While it is less problematic that the experience of these students is different, it must be our concern, as teachers of law, to ensure that at some point in the 3-year program we design and administer, the very fragility of law, its unattainedness ${ }^{85}$ and its status as 'not yet' 86 as a possible normative regulatory instrument of social

\footnotetext{
85 See Derrida, Force of Law. "The Mystical Foundation of Authority", 11 CARDOZO L. Rev. 921 (1990); see hereto the very fine interpretation by Orford, Critical Intimacy: Jacques Derrida and the Friendship of Politics, in: 6 GERMAN LAW Journal No. 1 (1 January 2005), forthcoming in a Special Dedication Section on the late Jacques Derrida with contributions, inter alia, by Peter Krapp, Adam Thurschwell, Friedrich Balke, Dirk Baecker, Drucilla Cornell, Pierre Schlag, Elisabeth Weber, Peter Goodrich, Simon Critchley, Petra Gehring and Costas Douzinas.

${ }^{86}$ Wiethölter, Begriffs- oder Interessenjurisprudenz. Falsche Fronten im IPR- und Wirtschaftsverfassungsrecht,

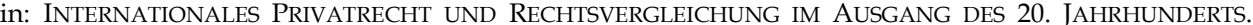
FESTSCHRIFT FÜR GERHARD KEGEL 213 (A. LÜDERITZ/J. SCHRÖDER EDS. 1977), at 234: “Es hilft nicht weiter, unsere Vergangenheit vor 1945 als positivistisch' und nach 1945 als ,nichtpositivistisch' zu würdigen. Einen Positivismus, der diesen Namen aus heutiger Sicht verdiente, hat es in der jüngeren Rechtsgeschichte (noch) nicht gegeben. Eine brauchbarere und zukunftsträchtigere Fragestellung ist es wohl, wie ,positives' Recht als zugleich ,richtiges' Recht denn zu gewährleisten sei." See also Wiethölter, Recht-Fertigungen eines Gesellschafts-Rechts, in: RECHTSVERFASSUNGSRECHT 13-21 (C JOERGES/G TEUBNER EDS. 2003); see hereto, Zumbansen, Das soziale Gedächtnis des Rechts, oder: Juristische Dogmatik als Standeskunst, in: (C JOERGES/G TEUBNER EDS. 2003), 151, 154.
} 
relations is communicated to the students. As we all know, this can be the case in every field of law. If we are more reluctant to pull away the carpet from underneath our straight-A doctrinal students in contracts and corporations, and more inclined to do so in Jurisprudence and Public International Law or in a course on "Law and the War on Terrorism," then we can hardly blame the students for this. Instead, it is probably due to our far progressed internalization of pressures and expectations associated with the competition among law schools or "good students, the job "market", the confusion over key qualifications, and, finally, the overall questionable status of legal education being provided by a "professional school." If we engage students in a Jurisprudence class in a discussion about formalism and positivism, but do not allow ourselves even to mention it in Contracts or Civil Procedure, it is most likely that for some students law school will remain an extremely exciting and enriching experience, while we as teachers have failed to reach many of them in teaching them about the constructed nature of legal reasoning and legal assessments. While we are afraid to even engage in the transformation of the First Year curriculum in order to stimulate among the school's faculty the willingness to raise a different set of questions and inquiries among the students about the fundamental rules in their 'basic' courses, we trod along and accept the teaching load in Lower year courses, but look immensely forward to our graduate seminar with the small group or our favorite students. So, who is to blame?

Eventually, we end up back to where we started. The transnational communication of legal experts remains the prerogative for the happy few on the international law circuit with the impressive sounding classes and the particular sort of students that vaguely imagine themselves working for an international organization sometime. We will happily specialize them, teach them about the International Criminal Court, maybe the strange creature called the European Union, occasionally add in a few insights from our international consulting work, and even allow our eyebrow to rise when referring to teachers who never moved beyond First Year Contracts. Sadly, our students will find nothing wrong with that as they themselves have understood the choice they made when enrolling in the International stream instead of joining the pack in Corporate Finance and Advanced Securities Law. Certainly, they are just as mistaken about the quality of education and about the law, too. While we will be able to teach them about the strange and fascinating replication of the "public" and the "private" in international legal discourse (e.g. the competition between criminal prosecution and transnational civil Human Rights litigation before domestic courts), it is already too late now, after they have taken all of their basic courses, to further explore this tension between 
public/private and politics and market as it unfolds within domestic law. ${ }^{87}$ Without a clear and solid connection within the curriculum between Legal Theory and International Law, and between those fields and the rest of the curriculum, students will leave law school, regardless of their having chosen this or that curricular stream, without any real understanding of the deep interpenetration of domestic legal concepts with conceptions of power and of culture, from near and far. They will also not see the way in which the critique of legal concepts within domestic law is indispensable for the learning of the 'language' of globalized law. ${ }^{88}$ Most likely, the experience of students leaving law school will have been diverse and at times also contingent, and more so than it should have been if there had been a more wide-spread consensus among their teachers about the importance of reflecting upon the changing nature of the beast whose structure, texture and colors they relate to them in exchange for a certain number of credits. Finally,

"The more wedded we become to a particular classification or definition, the more our thinking tends to become frozen and thus to have a rigidity which hampers progress toward the ever needed new solutions of problems whether old or new. Conflicts and laws are made by man. So are the theories which pronounce, for example, that international law cannot confer rights or impose duties directly on an individual because, says Theory, the individual is not a subject but an object of international law. It is not inappropriate here to invoke again the high authority of an earlier Storrs lecturer and to say with Cardozo: "Law and obedience to law are facts confirmed every day to us all in our experience of life. If the result of a definition is to make them seem to be illusions, so much the worse for the definition; we must enlarge it till it is broad enough to answer to realities." 89

\footnotetext{
87 See, e.g., Cutler, Artifice, Ideology and Paradox: the Public/Private Distinction in International Law, 4 Review Of InTERnational POltTical ECONOMY 261-285 (1997); Zumbansen, Sustaining Paradox Boundaries: Perspectives on the Internal Affairs in Domestic and International Law, 15 EUROPEAN JOURNAL OF INTERNATIONAL LAW [EJIL] 197-211 (2004).

${ }^{88}$ Schiff Berman, The Globalization of Jurisdiction, 151 U. PA. L. ReV. 311-545 (2002), at 323.

89 Philip Jessup, Transnational LaW 7 (1956), citing Cardozo, The Nature of the Judicial Process 127 (1921)
} 